\title{
EFFECT OF THE CONSUMPTION OF A CHEESE ENRICHED WITH PROBIOTIC ORGANISMS (BIFIDOBACTERIUM LACTIS BI-07) IN IMPROVING SYMPTOMS OF CONSTIPATION
}

\author{
Diane Cássia FAVRETTO', Bruna PONTIN² and Thaís Rodrigues MOREIRA ${ }^{3}$
}

\begin{abstract}
Context - Constipation is a very common symptom in the general population. One way of non-pharmacological treatment of constipation is through the addition of probiotics to food. Obectives - The aim of this study was to evaluate de effect of the consumption of a fresh cheese, enriched with Bifidobacterium lactis Bi-07 on the symptoms of constipated women. Methods - A randomized controlled trial, carried out in the Basic Health Units of Guaporés City - RS/Brazil, between january and may 2012, with 30 constipated women. The patients were randomized into two groups whom received, for 30 days, $30 \mathrm{~g}$ of fresh cheese enriched with Bifidobacterium lactis Bi-07 $(\mathrm{n}=15)$ or regular fresh cheese $(\mathrm{n}=15)$. Constipation symptoms were evaluated according to ROMA III Consensus, before and after the nutritional intervention. Also, data of clinical and anthropometric characteristics of the individuals were collected. Accepted level of significance $5 \%(P \leq 0,05)$. Results - The medium age of the studied population was $37,5 \pm 14,4$ years in the intervention group and 40,8 $\pm 12,8$ years in the control group. After 30 days we observed that the ingestion of fresh cheese enriched with Bifidobacterium lactis Bi-07 promoted benefic effects on the symptoms of strength to evacuate. Conclusion - The consumption of 30g/day of a fresh cheese enriched with Bifidobacterium lactis Bi-07 has beneficial effects on constipation symptoms.

HEADINGS - Constipation. Probiotics. Bifidobacterium. Cheese.
\end{abstract}

\section{INTRODUCTION}

Constipation, one of the most common digestive complaints in the general population, is not a disease in itself but a symptom present in many diseases ${ }^{(18)}$. After the first publication of the Rome Criteria for functional gastrointestinal disorders, epidemiological studies on the topic have used the following criteria to define constipation: effort to evacuate, hard or lumpy stools, sensation of incomplete evacuation, sensation of anorectal blockage or obstruction, manual maneuvers to facilitate defecations, and fewer than three defecations per week ${ }^{(6,19)}$.

The prevalence of intestinal constipation is variable, and depends on the location and the diagnostic criteria used. In the USA, a prevalence between $2 \%$ to $27 \%$ has been reported ${ }^{(1,7,14)}$, whereas in countries from Europe and Oceania the prevalence ranges from $5 \%$ to $35 \%{ }^{(20)}$. It affects more women than men, with a ratio of $2.1: 1$, and non-whites more than whites
$(1.68: 1)^{(14)}$. It can occur in all age groups, but is most common individuals older than 65 years and children under $4^{(3,9)}$. Constipation can be an initial symptom of serious diseases such as colorectal cancer, which is the fourth most common cancer among men and the third among women in Brazil ${ }^{(6,15,16)}$.

Symptoms of constipation, such as infrequent bowel movements, hard stools, difficulty for evacuate, cramping, bloating, flatulence, and sometimes severe abdominal pain, can affect the quality of life of patients ${ }^{(25)}$. In most cases, the main risk factors are improper eating habits, sedentary lifestyle, socioeconomic status, psychological parameters, medicines, age and gender ${ }^{(26)}$. The nutritional management with inclusion of probiotics in the diet represents an interesting non-pharmacological alternative for reducing the symptoms of constipation ${ }^{(12)}$. Probiotics are live bacteria, mainly bifidobacteria and lactobacilli, which are incorporated into food and, after ingestion, survive in the digestive tract of the host where they regulate

Declared conflict of interest of all authors: non

${ }^{1}$ Centro Universitário Univates, RS, Brasil; ${ }^{2}$ Instituto de Cardiologia do Rio Grande do Sul, Porto Alegre, RS, Brasil; ${ }^{3}$ Universidade Federal do Rio Grande do Sul, Porto Alegre, RS, Brasil.

Reserch performed at: Departamento de Nutrição, Centro Universitário Univates.

Correspondence: Thaís Rodrigues Moreira. Avenida Avelino Tallini, 171. Sala 216, prédio 11. Bairro Universitário - $95900-000$ - Lajeado, RS, Brasil. E-mail: th_rodrigues@ ibest.com.br 
the intestinal microbiota and have beneficial health effects ${ }^{(4)}$. The most commonly used species include Lactobacillus, Bifidobacterium and some species of Streptococcus, E. coli and yeast Saccharomyces cerevisiae (boulardi) ${ }^{(5)}$.

Constipation may be caused by intestinal dysbiosis, which is defined as an imbalance in the intestinal microbiota that has harmful effects on the integrity of the intestinal epithelium. It is characterized by an imbalance among the colonies of bacteria, with a prevalence of pathogenic bacteria ${ }^{(2)}$. Picard et al. ${ }^{(22)}$ and Szajewska et al. ${ }^{(24)}$ suggest that there is a dysbiosis of the intestinal flora in patients with constipation, which could be improved by consumption of probiotics. In addition, bifidobacteria may lower the $\mathrm{pH}$ of the colon, producing lactic acid, acetic acid, and others. A lower $\mathrm{pH}$ tends to increase colonic peristalsis and, in consequence, decrease colonic transit time, with a beneficial effect in the treatment of constipation symptoms.

Based on these considerations, the objective of this study was to evaluate the effect of consumption of Minas Frescal cheese, along with Bifidobacterium lactis $\mathrm{Bi}-07$, on the constipation symptoms in women.

\section{METHODS}

This randomized controlled trial was conducted in $\mathrm{Ba}-$ sic Health Units (BHU) of the city of Guaporé-RS/Brasil, between January and May 2012. Adult $(\geq 20$ and $<60$ years old), constipated women were included in the study. Women who (1) reported not eating cheese, due to taste preferences or food intolerance/allergy; (2) did not meet the criteria for constipation according to the ROME III Consensus ${ }^{(6,19)}$; and (3) were pregnant, were excluded. All participants were invited to participate in the study through Community Health Agents, during routine monthly visits. The participants were oriented to answer questions about the normal bowel habit, i.e. without the use of laxatives, teas or foods with probiotics.

The study was approved by the Research Ethics Committee of the Univates University Center, under protocol number 033/11, and all participants signed an informed consent form. This study was also approved in Clinical Trials, under protocol NCT01680432. At the beginning of the study, questionnaires were applied to characterize the sample and Rome III, which was applied before and after the intervention. In addition, the participants were nutritionally evaluated.

For characterization of the sample, lifestyle was assessed through the collection of data on gender, age, water and alcohol intake, physical activity, smoking, diagnosed pathologies and drugs used. Data were collected with use of an structured questionnaire, with closed and open questions.

For nutritional evaluation, weight and height were assessed and a 24-hour recalls were obtained. Weight measurement was performed with a portable digital scale $\left(\right.$ Plenna $\left.^{\circledR}\right)$, with a precision of $0.1 \mathrm{~kg}$ and capacity of up to $150 \mathrm{~kg}$. Height was determined with a vertical Sanny ${ }^{\circledR}$ stadiometer, with variation in centimeters, with the individuals standing barefoot, with feet together, no hair accessories ${ }^{(21)}$. Weight and height were used to calculate the body mass index (BMI), and participants were classified according to cut-off points established by the World Health Organization (1997): underweight (BMI $<18.5 \mathrm{~kg} / \mathrm{m}^{2}$ ), eutrophy (BMI 18.5 - 24.9 $\mathrm{kg} / \mathrm{m}^{2}$ ), overweight (BMI $25.0-29.9 \mathrm{~kg} / \mathrm{m}^{2}$ ), grade I obesity (BMI $30-34.9 \mathrm{~kg} / \mathrm{m}^{2}$ ), grade II obesity (BMI $35-39.9$ $\left.\mathrm{kg} / \mathrm{m}^{2}\right)$ and grade III obesity $\left(\mathrm{BMI} \geq 40 \mathrm{~kg} / \mathrm{m}^{2}\right)^{(21)}$.

Anthropometric data were collected by a researcher at the Community Hall of the Bom Jesus neighborhood and in the meeting room of the Family Health Strategy Social Centre, during the monthly meeting of nutritional education groups. The nutritional assessment and questionnaire were applied at home for individuals who could not attend the meeting, by the investigator. The 24-h recall data were used for calculation of energy value, carbohydrate, protein, lipids, fiber, total cholesterol, calcium, and iron. The software DietWin Professional $2.0^{\circledR}$ for evaluation and nutritional prescription was used for this calculation.

Thirty women with constipation were investigated. Constipation was defined according to the Rome III ${ }^{(19)}$ criteria, based on six criteria: (1) effort to evacuate, (2) hard or lumpy stools, (3) sensation of incomplete evacuation, (4) sensation of anorectal blockage or obstruction, (5) manual maneuvers to facilitate defecation and (6) fewer than three bowel movements per week. The presence of constipation was defined by the occurrence of two or more of these criteria, in at least $25 \%$ of the evacuations during the past 6 months (Table 1$)^{(6,18)}$.

TABLE 1. Questionnaire to define intestinal constipation, based on Rome III criteria

\begin{tabular}{|c|c|}
\hline \multicolumn{2}{|l|}{ Effort to evacuate } \\
\hline $\begin{array}{l}\text { (A) In the past six months, how often } \\
\text { have you had to force or make an effort to } \\
\text { defecate? }\end{array}$ & $\begin{array}{l}\text { (0) Never or rarely } \\
\text { (1) Sometimes } \\
\text { (2) Often } \\
\text { (3) Most of the times } \\
\text { (4) Always }\end{array}$ \\
\hline \multicolumn{2}{|l|}{ Hard or lumpy stools } \\
\hline $\begin{array}{l}\text { (B) In the past six months, how often did you } \\
\text { have hard stools, hardened or as if they were } \\
\text { marbles? }\end{array}$ & $\begin{array}{l}\text { (0) Never or rarely } \\
\text { (1) Sometimes } \\
\text { (2) Often } \\
\text { (3) Most of the times } \\
\text { (4) Always }\end{array}$ \\
\hline \multicolumn{2}{|l|}{ Sensation of incomplete evacuation } \\
\hline $\begin{array}{l}\text { (C) In the past six months, how often } \\
\text { have you had the sensation of incomplete } \\
\text { evacuation, i.e. even after evacuation, the } \\
\text { need remained? }\end{array}$ & $\begin{array}{l}\text { (0) Never or rarely } \\
\text { (1) Sometimes } \\
\text { (2) Often } \\
\text { (3) Most of the times } \\
\text { (4) Always }\end{array}$ \\
\hline \multicolumn{2}{|c|}{ Sensation of anorectal blockage or obstruction } \\
\hline $\begin{array}{l}\text { (D) In the past six months, how often have } \\
\text { you felt that the stool fail to pass, that it is } \\
\text { locked or trapped in the anus? }\end{array}$ & $\begin{array}{l}\text { (0) Never or rarely } \\
\text { (1) Sometimes } \\
\text { (2) Often } \\
\text { (3) Most of the times } \\
\text { (4) Always }\end{array}$ \\
\hline \multicolumn{2}{|c|}{ Manual maneuvers to facilitate defecation } \\
\hline $\begin{array}{l}\text { (E) In the past six months, how often have } \\
\text { you had to use your finger to help in the } \\
\text { passage of stool? }\end{array}$ & $\begin{array}{l}\text { (0) Never or rarely } \\
\text { (1) Sometimes } \\
\text { (2) Often } \\
\text { (3) Most of the times } \\
\text { (4) Always }\end{array}$ \\
\hline
\end{tabular}

Number of defecations per week

(F) How many times per week do you usually evacuate? 
The Rome Consensus for functional gastrointestinal disorders was developed to standardize the definition of constipation in epidemiological studies, as well as for the diagnosis in clinical practice $^{(6)}$. Furthermore, the American Gastroenterological Association guidelines recommend the Rome III criteria ${ }^{(18)}$.

For this study, the participants were randomized into one intervention and one control group, both with 15 participants. The intervention group received Minas Frescal cheese plus Bifidobacterium lactis $\mathrm{Bi}-07$, with $10^{8}$ colony-forming units per serving. Participants in the control group received Minas Frescal cheese without the addition of probiotics. The cheese was donated by a dairy industry, and was received in its commercial packaging. Since cheese is a highly perishable food, it was kept in its original packaging to minimize the risk of deterioration, so a blind study was not possible.

Nutritional intervention was performed between April and May 2012. Cheese was home delivered to all participants, on the same day and time. In order not to exceed the validity period of 35 days for the product in unopened packaging, it was delivered in two stages, with an interval of 15 days. The cheese was transported in thermal boxes, covered with ice cubes to keep temperature at $1^{\circ} \mathrm{C}$ to $8^{\circ} \mathrm{C}$, as determined by the manufacturer.

The two groups were instructed to consume one daily $30 \mathrm{~g}$ serving of cheese for 30 days, preferably at breakfast. Participants were also oriented on the conservation of the cheese, which should be consumed within 5 days after opening of the package, which was the expiration date established by the manufacturer. To determine the size of the portion, participants were shown photographs and cheese portions with the appropriate weight.

Participants were instructed about the probiotic properties and ways of consumption of cheese before the start of the distribution. The cheese with probiotics should not be heated, or the probiotic properties would be lost; in addition, it could be consumed in sandwich or salad forms. During the study, all participants were directed to keep their normal eating habits, physical activity and fluid intake, and not make use of other probiotic products.

After the intervention period, the ROME III questionnaire that had assessed the constipation symptoms at baseline was applied again for evaluation of any improvement of symptoms in the month during which the nutritional intervention occurred.

For statistical analysis, quantitative variables were described as mean and standard deviation or median and interquartile amplitude. Categorical variables were described as absolute and relative frequencies. The Student's $t$ test for independent samples was used for comparison of means among groups. In the case of asymmetry, the Mann-Whitney test was used. For comparison of proportions, the Pearson's Chi-square test or Fisher exact test were applied. The Wilcoxon test was used to evaluate the Rome III questionnaire before and after the intervention. Statistical analyses were performed with the software SPSS (Statistical Package for the Social Sciences) version 17.0. For all tests, the level of statistical significance of $95 \%(P \leq 0.05)$ was adopted.

\section{RESULTS}

As shown in Table 2 , the sample was composed entirely by women and age, weight, height and BMI were similar in the groups. According to the BMI classification, the intervention group had a prevalence of $66.7 \%(\mathrm{n}=10)$ overweight, followed by $20 \%(\mathrm{n}=3)$ eutrophy and $13.3 \%(\mathrm{n}=2)$ grade I obesity. In the control group, the distribution was $40 \%$ $(n=6)$ eutrophy, $26.7 \%(n=4)$ overweight, $20 \%(n=3)$ grade I obesity, $6.7 \%(n=1)$ grade II thinness and $6.7 \%(n=1)$ grade III obesity. The prevalence of associated diseases were $20 \%$ $(\mathrm{n}=6)$ for depression, 20\% $(\mathrm{n}=6)$ for hypercholesterolemia and $13,3 \%(\mathrm{n}=4)$ for hypertension, and no statistically significant differences were observed between the groups ( $P=0.651, P=1.000$ and $P=1.000$, respectively). The frequency of non-smokers was similar in the two groups $(93.3 \%$, $\mathrm{n}=28$ in the total sample), whereas the frequency of participants who reported drinking alcohol often was $20 \%$ $(n=3)$ in the intervention group and $26.7 \%(n=4)$ in the control group.

In both groups, $46.6 \%(n=7)$ of the participants reported using medicines and teas with laxative effect $(P=0.497)$. The use of drugs, especially antidepressants, was also investigated, due to its causal relationship with symptoms of constipation. The results showed that $26.7 \%(n=4)$ of the participants in the intervention group, and $13.3 \%(n=2)$ in the control group, made use of antidepressants.

No association between the use of drugs and constipation was observed in the intervention group after intervention $(P=1.000)$. However, in the control group, patients on

TABLE 2. Clinical and anthropometric characteristics of patients in the intervention and control groups in a randomized clinical trial

\begin{tabular}{lccc}
\hline Parameter & $\begin{array}{c}\text { Intervention } \\
(\mathbf{n}=15)\end{array}$ & $\begin{array}{c}\text { Control } \\
(\mathbf{n}=15)\end{array}$ & $\boldsymbol{P}$ \\
\hline Age (years) & $37.5 \pm 14.4$ & $40.8 \pm 12.8$ & $0.509^{*}$ \\
Weight $(\mathrm{kg})$ & $70.8 \pm 12.3$ & $67.6 \pm 18.4$ & $0.579^{*}$ \\
Height $(\mathrm{m})$ & $1.62 \pm 0.05$ & $1.58 \pm 0.06$ & $0.113^{*}$ \\
BMI $\left(\mathrm{kg} / \mathrm{m}^{2}\right)$ & $27.0 \pm 4.4$ & $27.0 \pm 7.4$ & $0.986^{*}$ \\
Physical activity & & & $1.000 \#$ \\
$\quad$ Yes & $8(53.3)$ & $7(46.7)$ & \\
No & $7(46.7)$ & $8(53.3)$ & \\
Use of probiotic & & & $0.651^{\#}$ \\
$\quad$ Yes & $4(26.7)$ & $2(13.3)$ & \\
$\quad$ No & $11(73.3)$ & $13(86.7)$ & \\
Type of probiotic & & & $0.505^{\#}$ \\
$\quad$ None & $11(73.3)$ & $13(86.7)$ & \\
B. animalis & $3(20.0)$ & $2(13.3)$ & \\
L. acidophillus + B. animalis & $1(6.7)$ & $0(0.0)$ & \\
Water ingestion & & & $0.557^{\#}$ \\
Up to 1 liter/day & $4(26.7)$ & $5(33.3)$ & \\
From 1 to 2 liters/day & $8(53.3)$ & $9(60.0)$ & \\
Above 2 liters/day & $3(20.0)$ & $1(6.7)$ & \\
*Student's $t$ test - data presented as mean and standard deviation; \# Chi-Square test
\end{tabular}


medication had significantly higher ratio of constipation after the treatment than participants who did not use these medicines $(P=0.041)$.

No statistically significant differences were observed between the intervention and control group in food consumption (Table 3). Results on the development of symptoms of constipation before and after intervention are presented in Table 4 .
After 30 days treatment, a positive effect in five of the six criteria assessed in the evaluation of Rome III criteria was observed in the intervention group. The control group showed improvements in three of these criteria. Although the symptoms of constipation improved in both groups, in the intervention group this improvement was significantly higher $(P<0.001)$.

TABLE 3. Data from 24-h recall in the intervention and control groups in a randomized clinical trial

\begin{tabular}{lccc}
\hline Nutrients & $\begin{array}{c}\text { Intervention } \\
(\mathbf{n}=15)\end{array}$ & $\begin{array}{c}\text { Control } \\
(\mathbf{n}=15)\end{array}$ & $\boldsymbol{P}$ \\
\hline Calories consumption (Kcal/day) & $1682 \pm 191$ & $1829 \pm 364$ & $0,176^{*}$ \\
Energy need/day (\% by HB) & $93,4 \pm 12,1$ & $106 \pm 21,7$ & $0,03^{*}$ \\
Energy need/day (\% by FAO/OMS) & $82,0 \pm 26,2$ & $94,8 \pm 21,3$ & $0,151^{*}$ \\
Carbohydrates g/day & $238 \pm 37,3$ & $272 \pm 73,1$ & $0,123^{*}$ \\
Carbohydrates \%/day & $57,2 \pm 7,2$ & $59,2 \pm 9,0$ & $0,509^{*}$ \\
Proteins g/day & $73,9 \pm 18,2$ & $74,0 \pm 24,1$ & $0,984^{*}$ \\
Proteins \%/day & $18,2 \pm 3,7$ & $16,4 \pm 5,0$ & $0,282^{*}$ \\
Lipids g/day & $46,3 \pm 16,4$ & $0,733^{*}$ \\
Lipids \%/day & $24,6 \pm 7,8$ & $0,938^{*}$ \\
Fibers g/day & $19,0(11,2-35,5)$ & $24,4 \pm 8,2$ & $0,512^{*}$ \\
Soluble fibers g/day & $1,55(0,13-3,27)$ & $28,6(12,6-34,5)$ & $0,713^{\#}$ \\
Insoluble fibers g/day & $1,64(0,08-3,28)$ & $1,39(0,90-2,15)$ & $0,345^{\#}$ \\
Total cholesterol mg/day & $137(99,2-191)$ & $2,62(2,01-3,67)$ & $0,539^{*}$ \\
Calcium mg/day & $689(481-968)$ & $235(97,1-291)$ & $0,174^{*}$ \\
Iron mg/day & $11,1(5,3-14,8)$ & $522(387-688)$ & $0,412^{*}$ \\
\hline
\end{tabular}

*Student's t test; " Mann-Whitney test; HB: Harris \& Benedict formula (1919); FAO/OMS: Formula Food and Agriculture Organization of the United Nations and Food/ World Health Organization (1985)

TABLE 4. Changes in symptoms of Rome III criteria assessed before and after the consumption of cheese with Bifidobacterium lactis Bi-07 in the intervention and control groups, in a randomized clinical trial

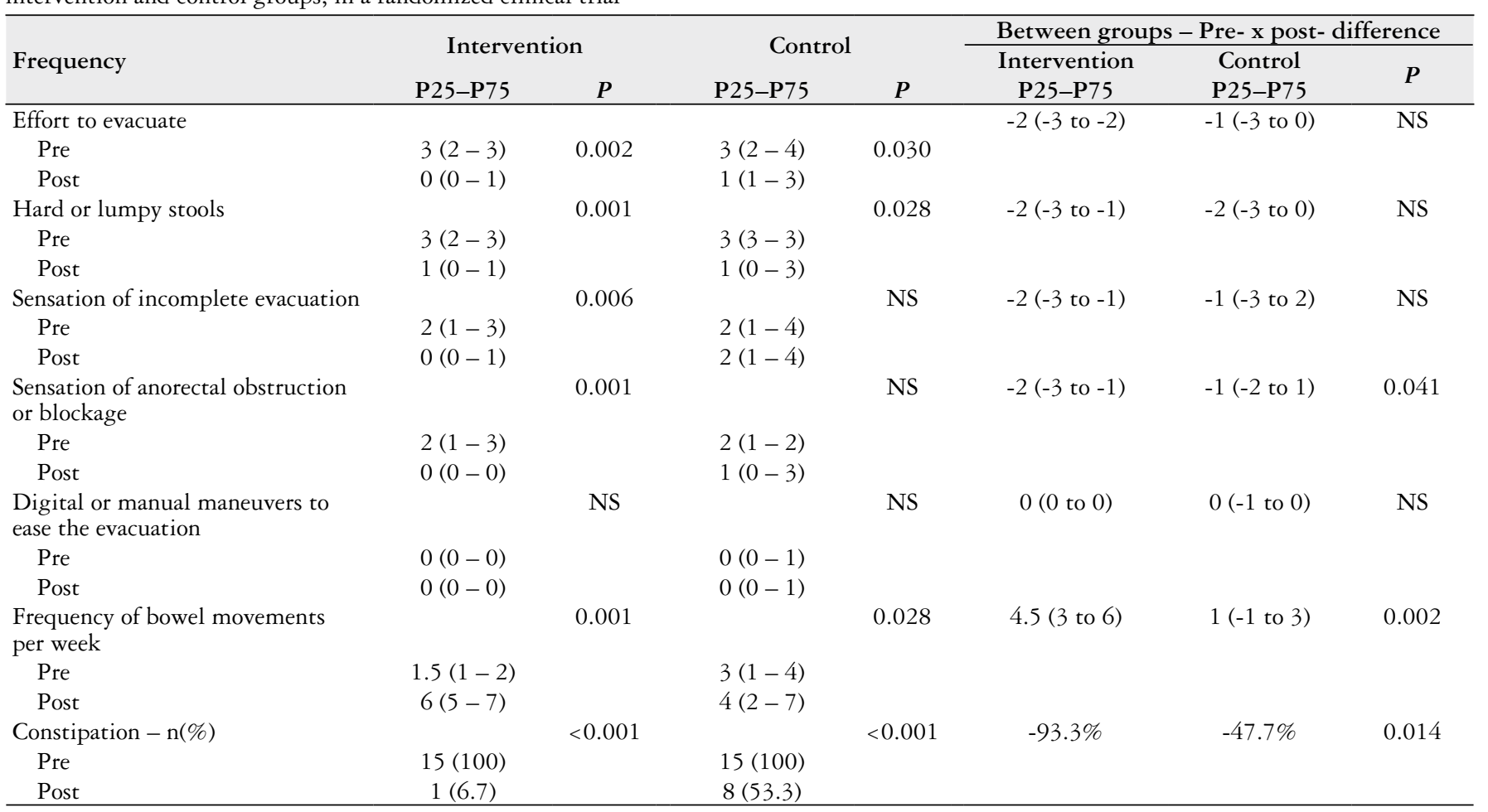

Wilcoxon test NS = non significant 


\section{DISCUSSION}

This study evaluated the effect of consumption of Minas Frescal cheese, along with Bifidobacterium lactis Bi-07, on the symptoms of constipation, as well as the nutritional status and food consumption of the participants. The results showed that daily consumption of this cheese has positive effects on symptoms of constipation. A prevalence of overweight in the intervention group and eutrophy in the control group were observed, and both groups had similar results in the analysis of food consumption.

The use of drugs with laxative action, which is causally associated with intestinal dysbiosis, was reported by the participants, but did not influence the results in the present work. Different results have been reported in similar studies. In the investigation of the prevalence and factors associated with intestinal constipation, Collete et al. ${ }^{(6)}$ found a prevalence of $22.4 \%$ of the use of laxatives in the sample, which was two times higher among women than among men $(47.0 \%$ vs $21.6 \%$, respectively). In a study to evaluate the benefits of oral supplementation with a symbiotic product ${ }^{(2)}$, the use of laxative was observed among $68.3 \%$ of patients with chronic constipation undergoing a weight loss diet. After 20 days of therapy, 110 patients used laxatives and in $78.4 \%$ of them $(\mathrm{n}=91)$ the constipation worsened. In the second period analyzed (40 days of treatment), 153 patients had used laxatives and a worsening of constipation was observed in 134 of them $(87.6 \%)$. In the third period (60 days), constipation worsened in $9.3 \%$ of all patients. Similar results were not observed in the present work, since the duration of the study was relatively shorter. Therefore the ingestion of probiotics has a role in the modulation of the intestinal microbiota composition that was affected, and also in the prevention of the pathogenic bacterial growth, correcting the dysbiosis and restoring bowel health ${ }^{(11)}$.

As observed for the characterization of the sample, the food consumption was also statistically similar between the intervention and control groups. Dietary factors, such as a low-fiber diet and low caloric intake, are associated with intestinal constipation ${ }^{(6)}$. Usually, adequate fiber consumption is associated with improvement of symptoms in functional constipation, and is the first measure recommended in the nutritional management of this condition ${ }^{(10)}$. In the present study, a higher fiber consumption was observed in the control group than in the intervention group, but even so, the improvement in the symptoms of constipation was higher in the intervention group. In both groups, there was a low intake of insoluble fibers, which is often associated with constipation. Román et al. ${ }^{(23)}$ evaluated the effect of the ingestion for 20 days of a dairy product prepared with $20 \mathrm{~g}$ of dietary fiber, and described a significant improvement in the six symptoms of Rome III criteria in the treated group. According to the 24-h recall, there was a greater caloric intake in the control group, though this result was not statistically significant. However, different results were observed in the study of Yang et al. ${ }^{(27)}$, who accompanied the total daily intake of the sample during the intervention with a fermented milk containing Bifidobacterium lactis DN-173010. Throughout the period observed, the control group showed a total caloric intake smaller than the test group.
In this study, consumption of a Minas Frescal cheese plus Bifidobacterium lactis Bi-07 improved the frequency of bowel movements and consistency of stools, as well as the conditions of defecation, in constipated patients. In the evaluation of the effect of a fermented milk containing Bifidobacterium lactis DN-173010 on constipated Chinese women ${ }^{(27)}$, Yang et al. observed a significant increase in the frequency of evacuations after one and two weeks of treatment $(40 \%$ and $58 \%$, respectively). In addition, the score of defecation was also improved after one week $(1.1 \pm 0.9$ vs $1.9 \pm 1.2)$ and 2 weeks $(0.8 \pm 1.0$ vs $1.9 \pm 1.2)$ of product consumption, as well as the consistency of the stools after one week $(1.0 \pm 0.8$ vs $1.5 \pm 1.1)$ and two weeks $(0.6 \pm 0.8$ vs $1.5 \pm 1.1)$ of treatment, respectively.

A beneficial effect was also observed in the perception of strength or effort to evacuate, in the sensation of incomplete evacuation and in the sensation of anorectal blockage. A study that evaluated the effect of the ingestion of a symbiotic yogurt on bowel habits in women with functional constipation $^{(8)}$ reported a significant increase in the frequency of evacuation, changes in the appearance of feces (with improvement in the Bristol scale), and significant reduction in the perception of strength and pain associated with defecation. According to the authors, the reduction in the sensation of pain and strength to evacuate represents the most important results, because they imply a significant reduction in the perception of unpleasant sensations.

Normal bowel habits, with no feelings of pain and control over bowel movements are important elements for the physical welfare ${ }^{(27)}$. Guyonnet et al. ${ }^{(13)}$ reported that daily consumption of fermented milk containing B. lactis DN-173010 improved the quality of life and symptoms in individuals with irritable bowel syndrome, compared to placebo. These results support the hypothesis of a relationship between increased frequency of bowel movements, bowel transit time, quality of life and fermented milk containing B. lactis DN-173010.

One of the limitations of the present study is its controlled and opened design, which resulted in the knowledge, by both researchers and participants, of the interventions. The fact that the participants knew they were taking a probiotic product, which has a regulatory effect on intestinal function, may have influenced the results observed in this study, although randomization of the sample may have minimized this bias. The lack of studies with the same sample characterization, similarly evaluating dietary habits and anthropometric and clinical conditions of the population, and with the same selection criteria, based on Rome III criteria, also influenced negatively in the discussion of the study, since the diagnostic criteria of similar studies is variable.

The results of this study demonstrate that regular ingestion of a cheese plus probiotic microorganisms (Bifidobacterium lactis $\mathrm{Bi}-07$ ) provides beneficial effects on symptoms of constipation, therefore becoming an alternative non-pharmacological management of these symptoms.

\section{ACKNOWLEDGMENTS}

We are thankful to the communitarian agents of health, nutritionist Luciane Messa Urrutigaray and participants of the study. 
Favretto DC, Pontin B, Moreira TR. Efeito da ingestão de um queijo acrescido de microrganismos probióticos (bifidobacterium lactis bi-07) na melhora de sintomas de constipação. Arq Gastroenterol. 2013,50(3):196-201.

RESUMO - Contexto - A constipação intestinal é um sintoma bastante comum na população em geral. Uma das formas de tratamento não farmacológico da constipação é através da adição de probióticos aos alimentos. Objetivos - O objetivo deste estudo foi avaliar o efeito do consumo de um queijo minas frescal, acrescido de Bifidobacterium lactis Bi-07 sobre os sintomas de mulheres constipadas. Métodos - Trata-se de um ensaio clínico randomizado e controlado, desenvolvido nas Unidades Básicas de Saúde da cidade de Guaporé- RS/Brasil, durante o período de janeiro a maio de 2012, envolvendo 30 mulheres constipadas, randomizadas em dois grupos que receberam, por 30 dias, $30 \mathrm{~g}$ de queijo minas frescal acrescido de Bifidobacterium lactis Bi-07 ( $\mathrm{n}=15)$ ou queijo minas frescal, sem adição de probióticos $(\mathrm{n}=15)$. Foram avaliados os sintomas de constipação de acordo com o Consenso de ROMA III antes e após a intervenção nutricional, além de características clínicas e antropométricas dos indivíduos. Resultados - As mulheres tinham

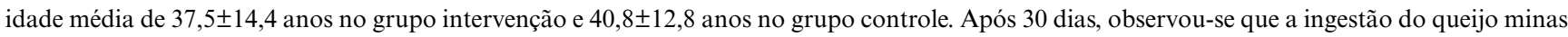
frescal acrescido de Bifidobacterium lactis Bi-07 promoveu efeitos benéficos nos sintomas de força ou esforço ao evacuar. Conclusão - Este estudo sugere que a ingestão de $30 \mathrm{~g}$ de queijo minas frescal acrescido de Bifidobacterium lactis Bi-07 melhora os sintomas de constipação.

DESCRITORES - Constipação intestinal. Probióticos. Bifidobacterium. Queijo.

\section{REFERENCES}

1. Adibi P, Behzad E, Pirzadeh S, Mohseni M. Bowel habit reference values and abnormalities in young Iranian healthy adults. Dig Dis Sci. 2007;52:1810-3.

2. Amenta M, Cascio MT, Di Fiore, P, Venturini I. Diet and chronic constipation. Benefits of oral supplementation with symbiotic zir fos (Bifidobacterium longum W11 + FOS Actilight). Acta Biomed. 2006;77:157-62.

3. Arce DA, Ermocilla CA, Costa H. Evaluation of constipation. Am Fam Physician. 2002;65:2283-90.

4. Cáceres P, Gotteland M. Alimentos probióticos en Chile: ¿Qué cepas y que propiedades saludables? Rev Chil Nutr. 2010;37:97-109. doi: 10.4067/S071775182010000100010 .

5. Cisternas CD. El uso de probióticos en el síndrome de intestino irritable y constipación. Acta Gastroenterol Latinoam. 2010;21:257-9.

6. Collete VL, Araújo CL, Madruga SW. Prevalência e fatores associados à constipação intestinal: um estudo de base populacional em Pelotas, Rio Grande do Sul, Brasil, 2007. Cad Saúde Pública. 2010;26:1391-402. doi: 10.1590/S0102311 X2010000700018.

7. Corazziari E. Definition and epidemiology of functional gastrointestinal disorders. Best Pract Res Clin Gastroenterol. 2004;18:613-31.

8. De Paula JA, Camuega E, Weill R. Effect of the ingestion of a symbiotic yogurt on the bowel habits of women with functional constipation. Acta Gastroenterol Latinoam. 2008;38:16-25.

9. Dennison C, Prasad M, Lloyd A, Bhattacharyya SK, Dhawan R, Coyne K. The health-related quality of life and economic burden of constipation. Pharmacoeconomics. 2005;23:461-76.

10. Foxx-Orestein AE, McNally MA, Odunsi ST. Update on constipation: one treatment does not fit all. Cleve Clin J Med. 2008;75:813-24.

11. Gerritsen J, Rijkers GT, Vos WM. Intestinal microbiota in human health and disease: the impact of probiotics. Genes Nutr. 2011;6:209-40.

12. Gotteland M, Vizcarra M, Maury E. Efecto de un product lácteo con probióticos e prebióticos sobre La funcion digestiva de sujetos sanos y constipados. Rev Chil Nutr. 2010;37:340-51. doi: 10.4067/S0717-75182010000300009.

13. Guyonnet D, Chassany O, Ducrotte P, Picard C, Mouret M, Mercier CH, Matuchansky C. Effect of a fermented milk containing Bifidobacterium animalis DN-173 010 on the health-related quality of life and symptoms in irritable bowel syndrome in aduts in primary care: a multicentre, randomized, double-blind, controlled trial. Aliment Pharmacol Ther. 2007;26:475-86.
14. Higgins PD, Johanson JF. Epidemiology of constipation in North America: a systematic review. Am J Gastroenterol. 2004;99:750-9.

15. Instituto Nacional de Câncer [Internet]. Incidência de câncer no Brasil, 2012 [cited 2012 Apr 23]. Available from:<http://www.inca.gov.br/ estimativa/2012>.

16. Lewis SJ, Heaton KW. The metabolic consequences of slow colonic transit. Am J Gastroenterol. 1999;94:2010-16.

17. Locke GR 3rd, Pemberton JH, Phillips SF. AGA technical review on constipation American Gastroenterological Association. Gastroenterology. 2000;119:1766-78

18. Longstreth GF, Thompson WG, Chey WD, Houghton LA, Mearin F, Spiller RC. Functional bowel disorders. Gastroenterology. 2006;130:1480-91.

19. Mollen RM, Claassen AT, Kuijpers JH. The evaluation and treatment of functional constipation. Scand J Gastroenterol Suppl. 1997; 223:8-17.

20. Peppas G, Alexiou VG, Mourtzoukou E, Falagas ME. Epidemiology of constipation in Europe and Oceania: a systematic review. BMC Gastroenterol. 2008;8:5

21. Physical status: the use and interpretation of anthropometry. Report of a WHO Expert Committee. World Health Organ Tech Rep Ser. 1995;854:1-452.

22. Picard C, Fioramonti J, Francois A, Robinson T, Neant F, Matuchansky C: Review article: bifidobacteria as probiotic agents - physiological effects and clinica benefits. Aliment Pharmacol Ther. 2005;22:495-512.

23. Román JL, Gonzálvez ABM, Luque A, Minãno JAP, Acosta AV, Iglesias JR, Hernández M, Villegas JA. Efecto de la ingesta de un preparado lácteo con fibra dietética sobre El estreñimiento crónico primario idiopático. Nutr Hosp. 2008;23:12-9.

24. Szajewska H, Setty M, Mrukowicz J, Guandalini S. Probiotics in gastrointestinal diseases in children: hard and not-so-hard evidence of efficacy. J Pediatr Gastroenterol Nutr. 2006;42:454-75.

25. Tack J, Müller-Lissner S. Treatment of chronic constipation: current pharmacological approaches and future directions. Clin Gastroenterol Hepatol. 2009;7:502-8.

26. World Gastroenterology Organisation Practice Guidelines Constipation [Internet]. Constipação: uma perspectiva mundial, 2010. [cited 2012 Apr 25] Available from: <http://www.worldgastroenterology.org/assets/export/userfiles/constipation_pt.pdf $>$.

27. Yang YX, He M, Hu G, Wei J, Pages P, Yang XH, Bourdu-Naturel S. Effect of a fermented milk containing Bifidobacterium lactis DN-173010 on Chinese constipated women. World J Gastroenterol. 2008;14:6237-43.

Received 25/4/2013 Accepted 15/5/2013 